\title{
Ecology of amorphous aggregations (marine snow) in the Northern Adriatic Sea. III. Zooplankton interactions with marine snow
}

\author{
Alexander B. Bochdansky, Gerhard J. Herndl* \\ Department of Marine Biology, Institute of Zoology, University of Vienna, Althanstraße 14, A-1090 Vienna, Austria
}

\begin{abstract}
The metazoan species composition in small stringer-shaped aggregates of marine snow from the Northern Adriatic Sea $(<2 \mathrm{~cm})$ was found to be distinctly different from the zooplankton community determined in ambient water Larval stages dominated the marine snow associated community, with polychaete larvae being most important in terms of biomass. Occasionally polychaete larvae exceeded bacterial biomass and metabolism in marine snow. Together with juvenile turbellarians, they were found to be enriched in marine snow by factors $>600$ as compared to the surrounding water. Polychaete larvae utilize marine snow as a transport vehicle and as a food source as directly observed under the dissecting microscope. During summer, the only copepods found significantly enriched in marine snow were harpacticoids and Temora stylifera, whereas the dominant mesozooplankton species in ambient water were Acartia clausi and Penilia avirostris. Neither $A$. clausi nor $P$. avirostris were found associated with marine snow. Grazing experiments with $A$. clausi, which is the dominant calanoid copepod in the Northern Adriatic Sea, revealed that this copepod does not feed significantly on the marine snow associated phytoplankton biomass. Thus we conclude that the major fraction of the free-living filter-feeding herbivorous zooplankton is unable to utilize phytoplankton when embedded in the mucoid matrix.
\end{abstract}

\section{INTRODUCTION}

Sinking of large amorphous aggregates (marine snow) has recently been identified as one of the major mechanisms by which particulate organic matter is transported into the deep ocean (Fowler \& Knauer 1986, Alldredge \& Silver 1988). It is well documented that marine snow is frequently enriched in inorganic and organic nutrients (McCarthy \& Goldman 1979, Shanks \& Trent 1979, Herndl \& Peduzzi 1988) as well as in various organisms, including phytoplankton (Knauer et al. 1982, Beers et al. 1986), bacteria (Alldredge et al. 1986), bacterivorous protozoa (Caron et al. 1982) and other microplankton (Silver et al. 1978). In terms of biomass, enrichment factors vary from 1.5 to 1000 depending on the source of the marine snow (Alldredge \& Gotschalk 1990). It is therefore reasonable to assume that marine snow exhibits high metabolic activity as has been shown in a number of studies (Knauer et al. 1982, Herndl 1988). These nu-

\footnotetext{
- Addressee for correspondence
}

trient-rich patches within the water column are a potential food source for planktonic metazoans.

Zooplankton contributes to particle flux through particle formation (Karl et al. 1988, Taylor 1989) via production of rapidly sinking fecal material and mucus feeding structures such as discarded appendicularian houses (Silver et al. 1984, Davoll \& Silver 1986). The role of zooplankton in degrading marine snow, however, has received much less attention, although marine snow may be a food source for zooplankton organisms (Baylor \& Sutcliffe 1963, Riley et al. 1964, Silver et al. 1978, Alldredge \& Silver 1988). Alldredge (1972) presented direct evidence that cyclopoid copepods of the genus Oncaea feed on abandoned larvacean houses. Recently, Banse (1990) hypothesized that zooplankton grazing on marine snow might be a key to resolving the particle decomposition paradox (Karl et al. 1988). Another indication that zooplankton might utilize marine snowmucus as a food source is the finding that the copepod Acartia negligens feeds on mucus sectreted by scleractinian corals assimilating up to $50 \%$ of the organic matter of the mucus (Richman et al. 1975). Another potential 
food source worth considering in marine snow are bacteria, which are too small to be filtered by copepods when freely in suspension. While single bacteria are too small to be effectively retained by the mesh of the maxillipeds (Nival \& Nival 1976), they could be ingested along with the mucus of marine snow.

In the Northern Adriatic Sea, marine snow appears in the stratified water column as a decay product of algal blooms. Aggregates can reach several meters in length (Cori 1906, Stachowitsch et al. 1990). Herndl (1988) has shown that the microbial biomass in marine snow increases during prolonged periods of stratification, while at the same time the ambient water is depleted of planktonic organisms. The water column, therefore, represents a highly structured and patchy environment under such conditions.

The aims of this study were (1) to determine whether there is a zooplankton community associated with marine snow distinctly different from the zooplankton consortia of the ambient water, (2) to determine whether some zooplankters are specifically enriched in marine snow and (3) to determine the potential role of marine snow as a food source for zooplankton organisms.

\section{MATERIAL AND METHODS}

The main study location was $1.5 \mathrm{~km}$ off the Laboratorio di Biologia Marina at Aurisina in the Gulf of Triest, Italy, (Northern Adriatic Sea) during 22 to 27 July, 22 to 26 August and 22 to 26 September 1990 Sampling was also performed off Piran, Slovenia, on 27 September 1989 and off Rovinj, Croatia, from 26 August to 4 September 1991. We selectively sampled marine snow with $60 \mathrm{ml}$ disposable syringes by SCUBA diving. Metazoan plankton of ambient water was sampled using diver-operated 0.81 hand-made plexiglass syringes since traditional net sampling was not possible due to the high abundance of marine snow in the water column. For each marine snow sample at least 10 times the volume was sampled without visible aggregates. Both marine snow and ambient water samples were brought back to the laboratory within $20 \mathrm{~min}$ for direct observations. We sorted living zooplankton organisms according to their taxonomic groups. The residual marine snow was used for dry weight and organic matter analysis.

The actual dry mass of marine snow was determined as described by Herndl (1988). Briefly, a $900 \mathrm{ml}$ plexiglass cylinder (inner diameter $4 \mathrm{~cm}$ ) was slowly moved through a selected depth layer and stoppered at both ends. For dry weight determination of marine snow, the contents of the plexiglass cylinders were filtered onto preweighed and precombusted Whatman GF/F glass fiber filters $(47 \mathrm{~mm}$ diameter $)$, rinsed 3 times with distilled water and dried at $60^{\circ} \mathrm{C}$ to constant weight; a control cylinder in which no visible aggregates were enclosed was treated in the same way and subtracted from the dry mass of the marine snow cylinder. For chl a we followed the description in Parsons et al. (1984).

In order to obtain an estimate on the carbon content of polychaete larvae, which were found to dominate the zooplankton biomass in marine snow, 6 ampoules were filled with 20 polychaete larvae each and stored at $-20^{\circ} \mathrm{C}$ in the dark. Prior to analyses, the samples were homogenized in a known volume of redistilled water and the organic carbon content was determined by a Beckmann TOC master $915-\mathrm{B}$ after acidifying $2 \mathrm{ml}$ of the suspension with $5 \mu \mathrm{l} 10 \% \mathrm{HCl}$ to $\mathrm{pH} 2$ and purging for 10 min with $\mathrm{CO}_{2}$-free air. Glucose was used as a standard.

As polychaete larvae were found to dominate the metazoan community in marine snow, their sinking velocities were determined in order to compare sinking rates of the larvae with marine snow. Formalin-killed larvae (1 drop of concentrated formalin in $20 \mathrm{ml}$ seawater) were carefully transferred into a $50 \mathrm{~cm}$ glass cylinder held at constant temperature. The body volume was estimated by measuring the length and width of the larvae and calculating the volume of a cylinder.

The palatability of marine snow associated phytoplankton was tested by measuring chl a and pheopigment concentration of the gut content of Acartia clausi, using the fluorometric technique described by Mackas \& Bohrer (1976) as modified by Dagg \& Wyman (1983). Between 30 and 50 individuals of $A$. clausi were placed in a $90 \%$ acetone-water solution, homogenized with a glass tissue grinder and subsequently filtered through a Whatman GF/F filter (47 mm diameter). A high sensitivity SPF-500 RATIO spectrofluorometer (American Instruments Co.) was calibrated with pure chl a (Sigma Chemicals) as a standard.

To determine the saturation threshold of food for adult Acartia clausi (males and females combined), 60 to 100 individuals of $A$. clausi were subjected to different concentrations of Nitzschia closterium (pennate diatom) in 1.1 plexiglass rolling tanks in dim light for $4 \mathrm{~h}$. The algal concentration was determined by measuring chl $a$ at the beginning and end of each experiment. After each experiment, 30 to 50 copepods were collected onto a $300 \mu \mathrm{m}$ Nitex screen and immediately transferred into a $90 \%$ acetone-water solution using fine forceps. Sampling was performed in duplicate.

In order to compare our results on the feeding pattern obtained in the laboratory with the diel feeding pattern under natural conditions we measured the total pigment content of Acartia clausi over a diel cycle in the natural environment. On 12-13 April 1990, 50 specimens of $A$. clausi were collected by net tows in $5 \mathrm{~m}$ 
depth over a $24 \mathrm{~h}$ period at $2 \mathrm{~h}$ sampling intervals using a $300 \mu \mathrm{m}$ plankton net. Specimens of A. clausi were preserved in $90 \%$ acetone within $10 \mathrm{~min}$.

Two experimental systems were set up to investigate the ability of Acartia clausi to prey on marine snow: (1) aggregates consisting of the diatom Nitzschia closterium only and (2) aggregates which were produced from natural seawater collected in the Gulf of Triest by rolling tank incubations (Shanks \& Edmondson 1989). For the first approach, dense $N$. closterium cultures in a stationary phase were incubated in Whatman GF/F filtered seawater in $10 \mathrm{l}$ plexiglass rolling tanks until a sufficient number of aggregates appeared (usually within $3 \mathrm{~d}$ ). Prior to exposing the aggregates to copepods, they were separated from suspended single cells by differential settlement. A $100 \mathrm{ml}$ glass cylinder was filled with Whatman GF/F filtered seawater and kept at $4{ }^{\circ} \mathrm{C}$. Aggregates were transferred from the rolling tanks $\left(18^{\circ} \mathrm{C}\right)$ into the surface layer of the glass cylinder with a wide-mouthed pipette. Due to the higher density of the $\left(4^{\circ} \mathrm{C}\right)$ cold water only larger aggregates settled to the bottom. In less than $5 \mathrm{~min}$, aggregates larger than $3 \mathrm{~mm}$ in diameter settled to the bottom while single cells remained in the upper part of the cylinder. Subsequently, the sedimented aggregates were collected again and the treatment described above was repeated twice. After 3 'rinses' no single cells were detectable at the bottom of the cylinder. The aggregates were then transferred to a rolling tank filled with $\mathrm{GF} / \mathrm{F}$ filtered seawater. In order to compare the potential of $A$. clausi to feed on food items of different stages of aggregation, we performed additional control experiments using $N$. closterium cultures which were filtered through a $65 \mu \mathrm{m}$ net and diluted to a density lower than $5 \mu \mathrm{g} \mathrm{chl} \mathrm{a} \mathrm{l}^{-1}$ ('single cells'). Filtered seawater served as control for the background fluorescence of copepods with empty guts. Sixty to 100 copepods (starved for $12 \mathrm{~h}$ ) with empty guts were introduced into $1 \mathrm{l}$ rolling tanks and incubated for $4 \mathrm{~h}$ in dim light at $18^{\circ} \mathrm{C}$. The chl $a$ and pheopigment content of the $N$. closterium single-cell suspension was measured before and after the experiment. To determine the amount of cells which came off the aggregates during the incubation, we measured also the chl a content of the aggregates and the ambient water after the experiment. After each experiment the copepods were collected and their gut pigment content determined as described above.

In the second experiment, aggregates were generated by rolling natural seawater as described by Shanks \& Edmondson (1989). The $10 \mathrm{l}$ rolling tanks were kept at $18^{\circ} \mathrm{C}$ and an illumination of $60 \mu \mathrm{E} \mathrm{m}^{-2} \mathrm{~s}^{-1}$ until aggregates appeared after $4 \mathrm{~d}$. Particles generated in this way were very similar to marine snow collected in summer 1990. Therefore, we subsequently refer to these aggregates as 'marine snow'. These aggregates were collected by a wide-mouthed pipette and washed in the same way as Nitzschia closterium aggregates. As control we used ambient water containing no visible particles; $0.2 \mu \mathrm{m}$ filtered seawater served as control for background fluorescence. Ambient water was filtered through a $65 \mu \mathrm{m}$ Nitex screen to eliminate or destroy all aggregates $>65 \mu \mathrm{m}$ in diameter. For each treatment, 50 to 100 copepods were put into 11 rolling tanks and incubated in dim light for $4 \mathrm{~h}$. After the experiment the fluorescence of the gut content of the copepods was measured as described before. The chl a and pheopigment concentrations of the water and the aggregates were measured as in the experiment with N. closterium.

As polychaete larvae were found to occur in high densities in marine snow and have been observed under the microscope to feed on marine snow, respiration measurements were performed to obtain an estimate on their energy demand. Although the determination of pigment concentrations in the gut is a powerful tool to examine the ingestion of algal-enriched food, it allows only limited predictions of the actual assimilation efficiency of ingested food. By measuring respiration it is possible to compare the ecological significance of the metazoan community with other living compartments in marine snow such as bacteria. Prionospio sp. larvae (Spionidae) were collected from marine snow samples. The larvae were incubated in $0.2 \mu \mathrm{m}$ filtered seawater (polycarbonate filter) for defecation for $1 \mathrm{~h}$ and subsequently rinsed twice in $0.2 \mu \mathrm{m}$ filtered seawater to remove the major fraction of bacteria prior to transfer into the incubation vessels (cartesian divers). For measuring the oxygen consumption, the cartesian diver method described in Zeuthen (1950) and Klekowski (1971) and as more recently described by Schiemer et al. (1990) was used. The 'background' respiration of the remaining bacteria was tested in empty divers and was below the detection limit of this method over a $3 \mathrm{~h}$ period. Antibiotics such as penicillin and chloramphenicol were not added since there is evidence that both affect respiration of eucaryots (Taylor \& Pace 1987). A single larva was introduced into the chamber. An air bubble with a known volume ranging from 2.47 to $3.32 \mu \mathrm{l}$ was placed next to the chamber. Once brought into the flotation vessel, the system was allowed to adapt to the respective temperature for at least 45 min before starting the measurement. The increase in specific gravity of the diver due to oxygen consumption was measured in $30 \mathrm{~min}$ intervals by applying negative pressure to the flotation vessel. Five readings were performed for each larva (total incubation period: 2.5 $\mathrm{h}$ per larva). The temperature was kept constant during the experimental procedure $\left(20.1^{\circ} \mathrm{C}\right)$. The read- 
ings in $\mathrm{mm}$ Brodie solution were converted into oxygen consumption by the formula:

$$
\mathrm{d} V \mathrm{O}_{2}=\left(V_{\mathrm{q}} \mathrm{d} P 273\right)\left(P_{0} T\right)^{-1}
$$

where $d V_{2}=$ rate of oxygen consumption $\left(\mu l \mathrm{~h}^{-1}\right) ; V_{\mathrm{q}}$ $=$ volume of the gas phase $(\mu l)_{i} d P=$ pressure change $\left(\mathrm{mm}\right.$ Brodie); $P_{0}=$ normal pressure for the system $(\mathrm{mm}$ Brodie); and $T=$ temperature of the system $\left({ }^{\circ} \mathrm{K}\right) . \mathrm{d} P$ in time was tested for linearity and averaged as $\mathrm{d} P \mathrm{~h}^{-1}$ before it was used for calculation.

\section{RESULTS}

\section{Overall characteristics of marine snow}

The abundance of marine snow probably of phytoplankton origin deviated only in a narrow range among the sampling dates. Dry weight of marine snow ranged from $6.3 \mathrm{~g}$ dry wt $\mathrm{m}^{-3}$ of seawater in July 1990 , to $7.8 \mathrm{~g}$ dry wt $\mathrm{m}^{-3}$ of seawater and $8.7 \mathrm{~g}$ dry wt $\mathrm{m}^{-3}$ of seawater in September 1990. The values are depth integrated from $10 \mathrm{~m}$ depth to the surface. In September
1989 and summer 1990, marine snow appeared in the forms of globules and stringers with a maximum length of $2 \mathrm{~cm}$ (for terminology of marine snow consult Stachowitsch et al. 1990). Bacterial density in marine snow did not change significantly during July and August $\left(1.4 \times 10^{6}\right.$ cells $\left.\mathrm{ml}^{-1}\right)$ and decreased in September $1990\left(4 \times 10^{5}\right.$ cells $\left.\mathrm{ml}^{-1}\right)$. Larger and denser aggregates (clouds) reaching several meters in length only appeared in summer 1991 and remained in the water column until September.

\section{The zooplankton community of marine snow}

Only the major groups of zooplankton inhabiting marine snow (such as polychaete larvae) or dominant species (like Convoluta aff. convoluta) were enumerated (Table 1). These groups or single species accounted for more than $90 \%$ of all living zooplankton organisms in marine snow. In September 1989 and July and September 1990, polychaete larvae were the most abundant organisms found in marine snow (Table $1 \mathrm{a}$ ), attached in a manner as shown in Fig. 1. In

Table 1. (a) Mean abundances of metazoans in 11 stringer-shaped marine snow during 1989 and 1990. Clouds were not present during this period. In order to compare abundances in marine snow and ambient water, enrichment factors (EF) are calculated on the basis of numbers per volume. $x$ indicates that no metazoan was found in the ambient water samples. As metazoan plankton abundances were similar in September 1989 and September 1990, the data were combined. (b) Comparison of the zooplankton composition between stringer shaped marine snow $(<2 \mathrm{~cm})$ and clouds $(>1 \mathrm{~m})$ during September 1991

\begin{tabular}{|c|c|c|c|c|c|c|c|c|c|}
\hline \multirow[t]{2}{*}{ (a) } & \multicolumn{3}{|c|}{$\begin{array}{l}\text { July } 1990 \\
(\mathrm{n}=6)\end{array}$} & \multicolumn{3}{|c|}{$\begin{array}{l}\text { August } 1990 \\
(\mathrm{n}=8)\end{array}$} & \multicolumn{3}{|c|}{$\begin{array}{c}\text { September } 1989 / 1990 \\
(n=13)\end{array}$} \\
\hline & Mean & Range & $\mathrm{EF}$ & Mean & Range & $\mathrm{EF}$ & Mean & Range & EF \\
\hline Polychaete larvae & 278 & $50-883$ & 344 & 217 & $50-617$ & 436 & 608 & $33-3633$ & 765 \\
\hline Juvenile turbellarians & 25 & $0-50$ & 62 & 123 & $17-217$ & $\infty$ & 192 & $17-1208$ & 670 \\
\hline Nauplii ${ }^{d}$ & 58 & $0-100$ & 145 & 406 & $50-783$ & 163 & 165 & $17-1233$ & 3.7 \\
\hline Harpacticoids & 39 & $0-100$ & 6 & 160 & $66-250$ & 3.5 & 96 & $0-242$ & 10 \\
\hline Temora stylifera ${ }^{\mathrm{a}}$ & 19 & $0-67$ & $\infty$ & 25 & $0-83$ & $x$ & 75 & $0-120$ & 200 \\
\hline Others & 19 & $0-50$ & 3.7 & 31 & $0-50$ & 2.2 & 41.7 & $0-83$ & 1.2 \\
\hline \multirow[t]{2}{*}{ (b) Type of aggregate: } & \multicolumn{4}{|c|}{$\begin{array}{c}\text { Stringers }(<2 \mathrm{~cm}) \\
(\mathrm{n}=12)\end{array}$} & \multicolumn{5}{|c|}{$\begin{array}{l}\text { Clouds }(>1 \mathrm{~m}) \\
(\mathrm{n}=10)\end{array}$} \\
\hline & \multicolumn{2}{|c|}{ Mean } & \multicolumn{2}{|c|}{ Range } & & Mean & \multicolumn{3}{|c|}{ Range } \\
\hline Polychaete larvae & \multicolumn{2}{|l|}{153} & \multicolumn{2}{|c|}{$10-367$} & & 0 & \multicolumn{3}{|c|}{0} \\
\hline Juvenile turbellarians & \multicolumn{2}{|l|}{22} & \multicolumn{2}{|c|}{$30-67$} & & 0 & \multicolumn{3}{|c|}{0} \\
\hline Nauplii & \multicolumn{2}{|l|}{263} & \multicolumn{2}{|c|}{$48-583$} & & 70 & \multicolumn{3}{|c|}{$13-233$} \\
\hline Other larvae & \multicolumn{2}{|l|}{0} & \multicolumn{2}{|c|}{0} & & 157 & \multicolumn{3}{|c|}{$73-375$} \\
\hline Harpacticoids & \multicolumn{2}{|l|}{110} & \multicolumn{2}{|c|}{$71-133$} & & 161 & \multicolumn{3}{|c|}{$118-291$} \\
\hline Penilia avirostris & \multicolumn{2}{|c|}{31.6} & \multicolumn{2}{|c|}{$0-190$} & & 95 & \multicolumn{3}{|c|}{$0-267$} \\
\hline Evadne sp. & \multicolumn{2}{|c|}{3.6} & \multicolumn{2}{|c|}{$0-20$} & & 32 & \multicolumn{3}{|c|}{$0-75$} \\
\hline Podon sp. & \multicolumn{2}{|c|}{1.9} & \multicolumn{2}{|c|}{$0-19$} & & 0 & \multicolumn{3}{|c|}{0} \\
\hline Acartia clausi & 0 & & & & & 35 & & $0-192$ & \\
\hline Others & 9.6 & & & & & 47 & & - & \\
\hline Dead animals or exuviae & 732 & & 108 & 136 & & 1765 & & $483-4367$ & \\
\hline
\end{tabular}


August 1990, nauplii exceeded the polychaetes in terms of numbers but not in biomass, since nauplii were at least 10 times smaller according to their body length. During September 1991, samples were more heterogeneous than during all other sampling periods Polychaete larvae appeared only in small stringers and at lower densities than in 1989 and 1990 (Table 1). As compared to small stringers, large and dense clouds showed a remarkably different composition of the zooplankton community. These aggregates contained many exuviae and dead or presumably trapped animals which might be an indication of their age (Table 1b). In general, the abundance of living zooplankton in these clouds was about half the abundance found in stringers.

The body volume of the polychaete larvae ranged from 0.0016 to $0.41 \mathrm{~mm}^{3}$ per larvae with a mean ( $\pm \mathrm{SD}$ ) of $0.036 \pm 0.08 \mathrm{~mm}^{3}(\mathrm{n}=34)$ in July $1990,0.02 \pm 0.005$ $\mathrm{mm}^{3}(\mathrm{n}=31)$ in September 1990 and $0.012 \pm 0.0046$ $(\mathrm{n}=8)$ in September 1991. The total organic carbon (TOC) content of polychaete larvae amounted to $6.4 \times$ $10^{-4} \pm 3 \times 10^{-4} \mathrm{mg} \mathrm{C}$ ind. $^{-1}(\mathrm{n}=6)$. The mean sinking
Fig. 1. In situ photograph of 2 polychaete larvae (arrows) attached to a marine snowstringer. Scale bar $=1 \mathrm{~mm}$

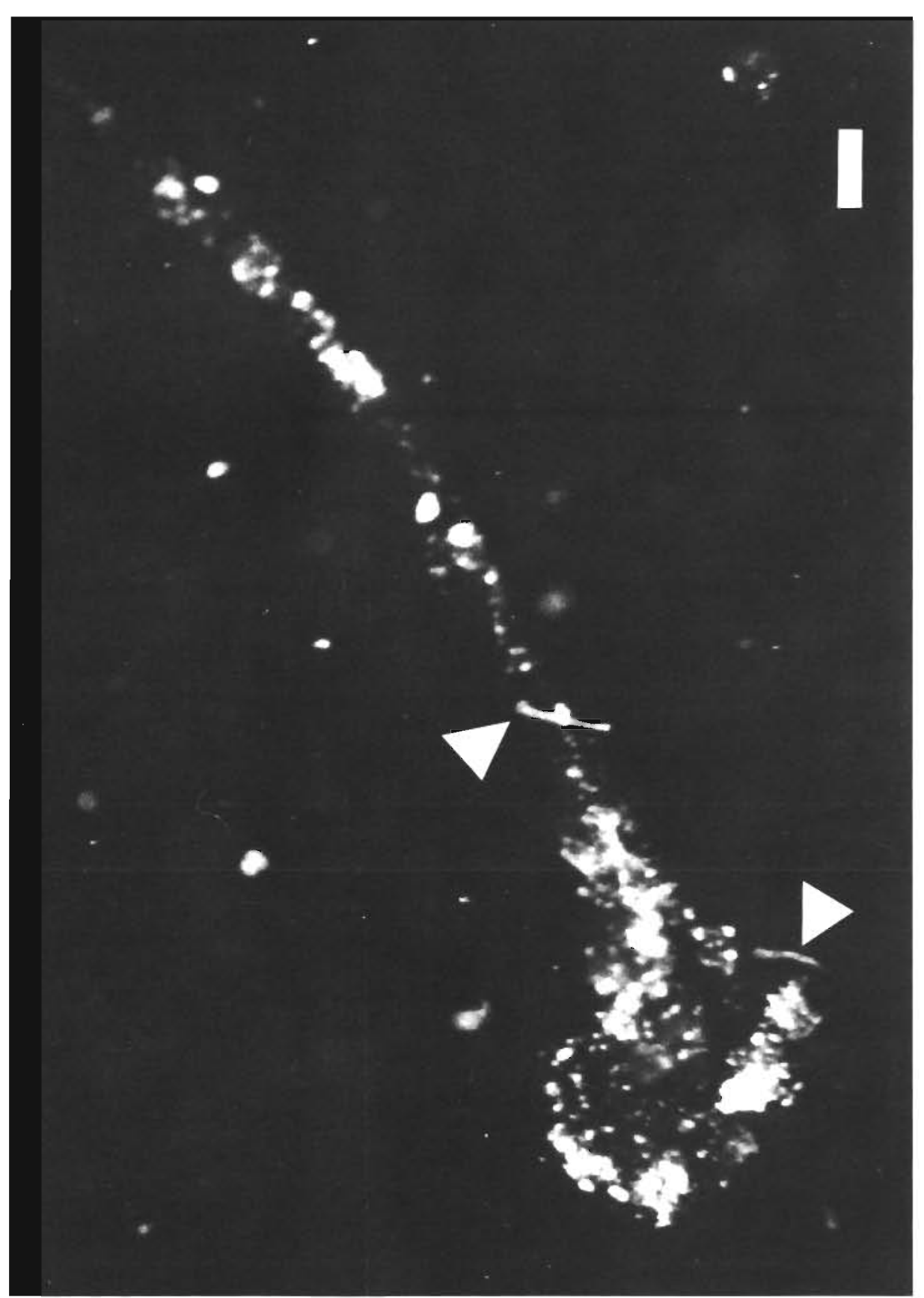


velocity of killed larvae was $71.6 \pm 23.8 \mathrm{~m} \mathrm{~d}^{-1}(\mathrm{n}=24)$. The majority of the polychaetes belonged to the Nectochaeta stage with long embryonal setigers tightly kept along the body surface during gliding through the organic matrix of marine snow. Taxonomically, the nectochaetes found in our samples belonged to 4 species of 3 families: the Spionidae, Nereidae and Disomidae. Most abundant was the genus Prionospio (Spionidae) with about $73 \%$ of the total number of nectochaetes, other spionids represented $8 \%$, Neireidae $14 \%$ and Poecilochaetus serpens about $5 \%$. In July, we found a few individuals of the Metatrochophora of Chaetopterus variopedatus in the marine snow samples. The turbellarians found in the samples were all juvenile acoeles. Although there were considerable uncertainties as to which species they actually belonged, they all carried endosymbiontic algae and fit well into the descriptions of adult Convoluta aff. convoluta which is a very common Acoela in the Northern Adriatic Sea living mainly in the phytal. Although their number did not exceed the number of polychaetes, nauplii, or harpacticoid copepods, the enrichment factor calculated for $C$. aff. convoluta was higher than in all other groups except for polychaetes. In both marine snow and ambient water nauplii significantly contributed to the microzooplankton. The harpacticoid copepods were abundant; compared to the other groups, however, they were only weakly enriched in the aggregates (Table 1). Temora stylifera was the only calanoid copepod found enriched in marine snow during 1989 and 1990. We observed very few individuals of the cladoceran dominated zooplankton community which adhered to the stringers. In September 1991 many more specimens - mainly of the species Penilia avirostris - became entangled in large clouds. The remaining zooplankton (Metazoa) are summarized in Table 1 as 'others' and consisted of cyclopoid copepods, cladocerans, copepodite stages, appendicularians, plutei and veliger larvae, but accounted for less than $10 \%$ of the zooplankton in marine snow in terms of numbers. As revealed by direct observations and video analyses of polychaete larvae in petri dishes under the dissecting microscope the polychaete larvae exhibited 2 different feeding patterns: The nectochaetes and the Metatrochophora of C. variopedatus both were capable of swallowing the mucus matrix of marine snow directly Alternatively they fed on ciliates and other small particles using their ciliated girdle. The fecal pellets produced were highly variable in length (from 0.05 to $1.3 \mathrm{~mm}$ ), not very compact and remained in the matrix of marine snow. Additionally to polychaete larvae, larger nauplii and $T$. stylifera have been observed feeding on marine snow under the dissecting microscope (as indicated by the superscript ' $a$ ' in Table 1).

\section{Grazing experiments with Acartia clausi}

When grazing on single cells of Nitzschia closterium, the total gut pigment content of Acartia clausi was linearly correlated with the chl a concentrations of the algal suspension and reached a maximum gut content of $2.2 \mathrm{ng}$ chl $a$ ind. ${ }^{-1}$ at an algal concentration of 5 $\mu \mathrm{g}$ chl $a \mathrm{l}^{-1}$. At chl a concentrations ranging from 5 to $24 \mu \mathrm{g} \mathrm{chl} \mathrm{a} \mathrm{l}^{-1}$, there was no further increase in the gut pigment content. In laboratory feeding experiments with $N$. closterium, the gut fluorescence values were significantly higher (Mann-Whitney 2-sample test, p < 0.01 ) in the single cell treatment than in experiments where aggregates of $N$. closterium were offered (Table 2, Fig. 2). In the second experiment using marine snow as aggregated food source, A. clausi ingested significantly more plant pigments in natural seawater with no visible aggregates than during marine snow exposure (Mann-Whitney 2-sample test, $p<0.01$ Table 2, Fig. 2). The gut fluorescence of A. clausi measured in the Gulf of Trieste was much lower than in the feeding experiments with $N$. closterium. Over the diel cycle, the pigment content varied between $0.05 \mathrm{ng}$ per copepod at 8:00 $\mathrm{h}$ and $0.23 \mathrm{ng}$ per copepod at $2: 00 \mathrm{~h}$ (Fig. 3). The algal concentration during the sampling period was $0.8 \mu \mathrm{g} \mathrm{chl} \mathrm{a} \mathrm{l}^{-1}$ at $3 \mathrm{~m}$,

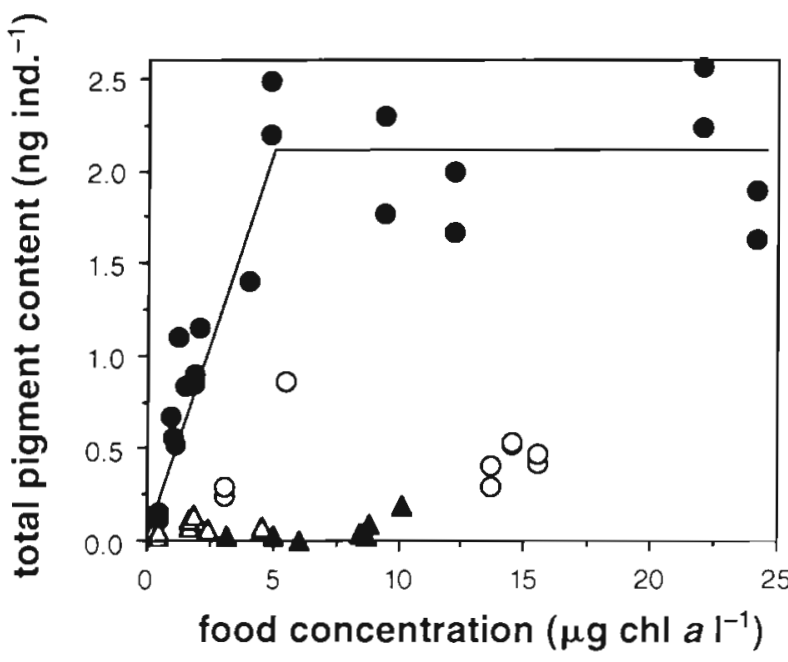

Fig. 2. Acartia clausi. Pigment concentration in the gut as dependent on food source: Nitzschia closterium aggregates $(\Delta)$, single cells of $N$. closterium ( $\bullet$ ), marine snow $(\Delta)$ and natural aggregate-free seawater (O). Each point represents the mean of 30 to 50 copepods. Triangles indicate chl a concentration in aggregates normalized to $1 \mathrm{l}$ bottle volume; thus chl a was highly concentrated in the aggregates. Line indrcates the relation of $A$. clausi gut pigment content to concentration of $N$. closterium single cells (measured as chl a) afțer $4 \mathrm{~h}$ of incubation. Up to a chl a concentration of $5 \mathrm{ug} \mathrm{l}^{-1}$. the relation to gut content is directly proportional: $y=0.14+$ $0.43 \times\left(\mathrm{r}^{2}=0.893, \mathrm{n}=14, \mathrm{p}<0.001\right)$. At chl a concentrations of more than $5 \mu \mathrm{g} \mathrm{l^{-1 }}$, gut content reaches saturation 
Fig. 3. Acartia clausi. Diel variation in total pigment content (chl $a$ and pheopigments) in the Gulf of Trieste (Northern Adriatic Sea) in April 1990. Bars indicate range of 2 subsamples

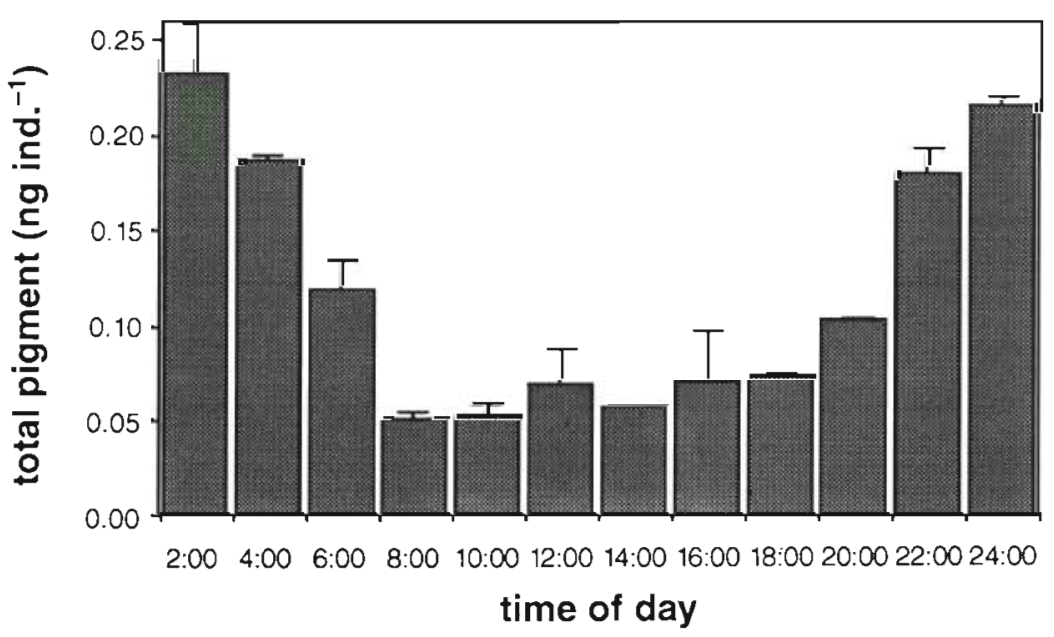

DISCUSSION

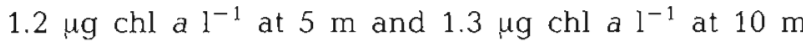
depth.

\section{Oxygen consumption of Prionospio sp. larvae}

The average oxygen consumption ( \pm SD) of Prionospio sp. larvae was $5.19 \pm 1.55 \mathrm{nl} \mathrm{O}_{2}$ ind $^{-1} \mathrm{~h}^{-1}(\mathrm{n}=11)$. Fig. 4 demonstrates the dependence of the oxygen consumption on the body volume. The relation of the body volume and the respiration of an organism is best described by the equation $R=a V^{b}$, where $R=$ respiration; $V=$ volume of an organism; $a$ and $b$ are constants calculated by the linear regression of the log-transformed $R$ and $V$ values. Using the respiration data of the polychaete larvae in $\mathrm{nl} \mathrm{O}_{2} \mathrm{~h}^{-1}$ and their body volume in $\mathrm{mm}^{3}, a=275.7$ and $b=0.90$.
Feeding activity in Acartia clausi exhibited a distinct diel cycle (Fig. 3). These field data are of the same order of magnitude as data obtained from A. clausi fed on natural aggregate-free seawater in our experiments (Fig. 2) much lower, however, than the values obtained in grazing experiments with a single cell suspension of Nitzschia closterium (Fig. 2). This indicates that food with little or no chl a comprises a major fraction of the diet of this copepod in the Northern Adriatic Sea. Omnivory is also described for other copepod species (Gaudy 1974, Lonsdale et al. 1979. Sheldon et al. 1986, Gifford \& Dagg 1988, Wiadnyana \& Rassoulzadegan 1989, Stoecker \& Capuzzo 1990).

The mechanism of selection seems to be triggered by the motion of the prey, whereas chemoreception is

Table 2. Experiments performed with Nitzschia closterium aggregates (a) and marine snow produced in rolling tanks using natural seawater (b). Chl a content of the algae exposed to the copepods and total pigment content of the copepods after the incubation are given as mean values and ranges of all replicates. Surrounding water: filtered seawater containing cells which became detached from the aggregates during the experimental procedure; $(-)$ not determined

\begin{tabular}{|c|c|c|c|c|c|}
\hline \multirow[t]{2}{*}{ Treatment } & \multirow[t]{2}{*}{$n$} & \multicolumn{2}{|c|}{$\begin{array}{l}\text { Food concentration } \\
\text { chl } a \mu \mathrm{gl}^{-1}\end{array}$} & \multicolumn{2}{|c|}{$\begin{array}{c}\text { Gut content } \\
(\text { ng copepod } \\
-1)\end{array}$} \\
\hline & & Average & Range & Average & Range \\
\hline \multicolumn{6}{|l|}{ (a) Nitzschia closterium } \\
\hline GF/F filtered seawater & 7 & 0.025 & $0.006-0.08$ & 0.024 & $0.006-0.042$ \\
\hline Single cells & 7 & 1.63 & $0.87-1.73$ & 1.0 & $0.53-1.57$ \\
\hline Aggregates & 7 & 7.18 & $3.2-10.09$ & 0.055 & $0.01-0.08$ \\
\hline Surrounding water & 7 & 0.073 & $0.028-0.092$ & & \\
\hline \multicolumn{6}{|l|}{ (b) Marine snow } \\
\hline GF/F filtered seawater & 8 & - & - & 0.025 & $0.01-0.038$ \\
\hline $\begin{array}{l}\text { Aggregate-free water } \\
\text { (63 } \mathrm{mm} \text { filtered) }\end{array}$ & 9 & 10.39 & $3.05-15.45$ & 0.46 & $0.28-0.86$ \\
\hline Aggregates & 9 & 2.22 & $0.55-4.60$ & 0.074 & $0.028-0.14$ \\
\hline
\end{tabular}




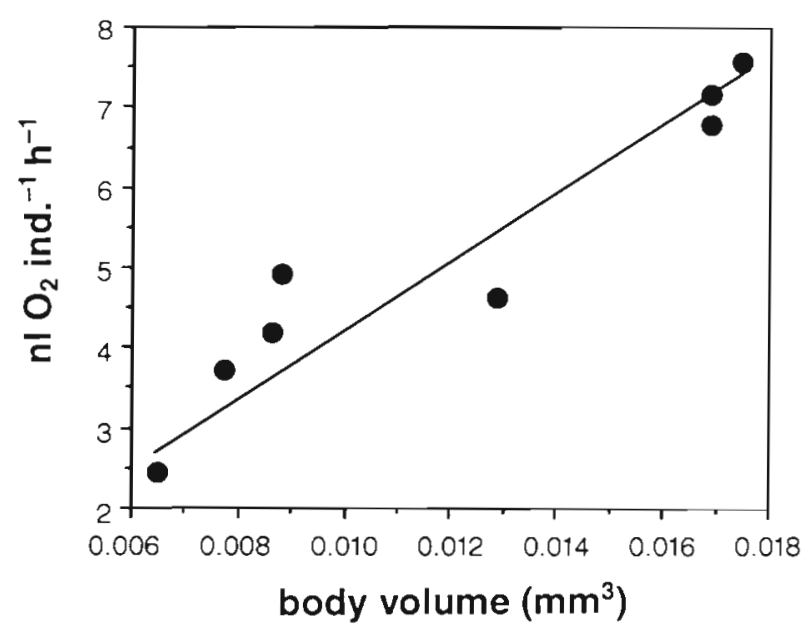

Fig. 4. Prionospio sp. Dependence of respiration rates on biomass. The curve represents the respiration rates derived from the formula $R=275.7 \mathrm{~V}^{-0.9}$, where $R=$ respiration (nl $\mathrm{O}_{2}$ ind $\left.{ }^{-1} \mathrm{~h}^{-1}\right)$ and $V=$ body volume $\left(\mathrm{mm}^{3}\right.$

probably of minor importance for prey detection (Jonsson \& Tiselius 1990). Potential grazing on large motionless particles, however, requires a very different behavior including the ability to rupture aggregates much larger than the usual prey. In our experiments the pigment concentration in the gut of Acartia clausi exposed to aggregates of Nitzschia closterium did not correlate with the chl a concentrations in the aggregates and were much lower compared to the values derived from the single cell treatment (Fig. 2). In incubations with marine snow the copepods displayed significantly lower gut-content values than those fed on natural seawater (Table $2 b$ ). If $A$. clausi can take advantage of the patchy distribution of food by ingesting attached phytoplankton along with marine snow, much higher total pigment contents would have been detected in the guts. However, only insignificantly higher pigment contents were detected after incubations with marine snow compared to copepods kept in filtered seawater. This slight increase can be explained by algae coming off the aggregates during the feeding experiment since it was not possible to keep all algae attached to the aggregates during $4 \mathrm{~h}$ incubation, as demonstrated in experiments with $N$ closterium monospecific aggregates (Table 2a). In our feeding experiments we assume that the chl a:carbon ratio is the same in marine snow and ambient water; this, however, might not necessarily be true although we sampled marine snow and ambient water from the same tank. The grazing experuments with $N$. closterium indicate that the low pigment concentrations in the guts in the marine snow treatment is not caused by the different chl a:carbon ratio but by the inability of A. clausi to prey on aggregates (and especially their associated phytoplankton). Concerning feeding on algae in different shapes, Schnack (1983) reported a very similar behavior of Temora stylifera, Calanus helgolandicus, Centropages chierchiae and Calanus carinatus. In her study, Thalassiosira partheneia was offered as prey in 2 different forms: as single cells and whole colonies. It appeared that the copepods are not able to feed on whole colonies of this algae, but ingested single cells after disintegration. Schnack (1983) further hypothesized that even raptorially feeding species are discouraged by colony formation and the mucoid halo of the algae.

Temora stylifera was the only calanoid copepod enriched in the aggregates and has been observed grazing on marine snow during this study. This species is known to be strongly predatory. Gaudy (1974) compared Acartia clausi and T. stylifera and found a preference for algal diet for $A$. clausi $T$. stylifera, however, can be considered as both herbi- and carnivore with a remarkable ability to prey even on large Artemia salina nauplii. Searching for a morphological manifestation of the different behavior of Acartia clausi and $T$. stylifera concerning grazing on marine snow, we found differences in their feeding appendages. $T$. stylifera has massive mandibular cutting edges, whereas the cutting edges of $A$. clausi are more fragile. We measured the teeth on the mandibular edges and calculated the edge index according to the formula given by Itho $(1970 ;$ cited in Omori \& Ikeda 1984). Both copepods belong to omnivore types; A. clausi tends towards herbivory and $T$. stylifera towards carnivory. Also the long setae of the first maxilliped of $A$. clausi which cover a large area indicate a preference for filtering small particles. The large mandibles and the reduced length of the maxilliped setae of $T$. stylifera, on the contrary, seem to be more suitable for grabbing larger particles including marine snow. Nevertheless the importance of marine snow contributing to the metabolic demand of $T$. stylifera remains unknown.

The cladoceran Penilia avirostris is the most dominant species in the mesozooplankton community of the Northern Adriatic Sea during summer (Fonda Umani 1985). P. avirostris feeds on smaller cells than Acartia clausi (Fonda Umanj \& Cocchietto 1988) and prefers nanoflagellates ( 2 to $5 \mu \mathrm{m}$ in diameter) over small diatoms (4 to $12 \mu \mathrm{m}$ in diameter) (Turner et al. 1988). Therefore it is likely that $P$. avirostris is not able to feed on marine snow either. Moreover, the morphology of its carapace, which encloses even the limbs, most probably prevents this animal from grazing on larger particles (presumably gathering small particles only by filtration). A. clausi and $P$. avirostris together comprise 30 to 
$90 \%$ of the total mesozooplankton biomass during the summer months. Thus we may conclude that algae embedded in the mucoid matrix remain ungrazed by most of the zooplankters present in ambient water.

The metazoans embedded in the aggregates were dominated by polychaete larvae, juvenile acoele turbellarians, nauplii and harpacticoid copepods. The species composition was very similar during 1989, 1990 and in the small stringers of 1991. This is surprising because one might expect fluctuations of organisms due to pulses of larval dispersal. These organisms exhibited enrichment factors ranging from 3.5 to 765 . In terms of biomass, polychaete larvae dominate the metazoan microzooplankton community in marine snow. Spionidae are known to spawn in summer (Riedl 1985) and subsequently comprise a significant portion of the microzooplankton community. For July 1990, the biomass of the polychaete larvae in terms of carbon represented $178 \mu \mathrm{g} \mathrm{C}^{-1}$ while the bacterial biomass amounted only to $26.4 \mu \mathrm{g} \mathrm{Cl}^{-1}$ (conversion factor: $20 \mathrm{fg}$ $\mathrm{C} \mathrm{cell}^{-1}$ ) in marine snow (Karner $\&$ Herndl 1992). These exceptionally high biomass concentrations for pelagic polychaete larvae can only be explained by the attachment to a substrate providing both food and a transport vehicle (discussed later). While the biomass ratio in terms of carbon of polychaete larvae:bacteria in July 1990 is 6.7 in marine snow, this ratio for the ambient water is only 0.064 . Our respiration data provide information on the carbon demand for catabolism of the polychaete larvae. To convert the $\mathrm{O}_{2}$-consumption rates into carbon equivalents we used the formula:

$$
C=R \mathrm{RQ}(12 / 22.4),
$$

where $C=$ carbon equivalent ( $\mu \mathrm{g} C$ animal $^{-1} \mathrm{~h}^{-1}$ ), $R=$ respiration rate $\left(\mu \mathrm{l} \mathrm{O}{ }_{2}\right.$ animal $\left.{ }^{-1} \mathrm{~h}^{-1}\right)$ and $12 / 22.4=$ the weight $(12 \mathrm{~g})$ of carbon in $1 \mathrm{~mol}(22.4 \mathrm{l})$ of carbon dioxide. $R Q$, the respiratory quotient, changes as a function of the excretory product and is 0.97 for ammonia (Gnaiger 1983). Since marine zooplankton is primarily ammonotelic (Omori \& Ikeda 1984) we used 0.97 for the RQ. $R$ is calculated for an average body volume of $0.012 \mathrm{~mm}^{3}$ using the equation $R=275.7 \mathrm{~V}^{0.9}$. The mean $\mathrm{O}_{2}$ consumption rate is therefore $0.124 \mu \mathrm{l} \mathrm{O}$ ind. ${ }^{-1} \mathrm{~d}^{-1}$, or in terms of carbon $0.064 \mu \mathrm{g} \mathrm{C}$ ind. ${ }^{-1} \mathrm{~d}^{-1}$. Since no data are available on the net growth efficiency of polychaete larvae, we took an average net growth efficiency of 30 to $70 \%$ as has been given for crustacean zooplankton by Conover (1968; cited in Raymont 1983); therefore we estimated the actual carbon demand for the polychaete larvae as 0.09 to $0.22 \mu \mathrm{g} \mathrm{C}$ ind ${ }^{-1} \mathrm{~d}^{-1}$; multiplying this value with the average number of polychaete larvae present in marine snow in July 1990, we arrive at an organic carbon demand for the polychaete larval community in marine snow of 25 to $60 \mu \mathrm{g} \mathrm{C}^{-1} \mathrm{~d}^{-1}$, which is in the same order of magnitude as the calculated bacterial carbon demand of $30 \mu \mathrm{g} \mathrm{C} \mathrm{l}^{-1} \mathrm{~d}^{-1}$ in July 1990 (recalculated from Karner \& Herndl 1992). This indicates that the turnover of carbon due to the activity of polychaete larvae can even exceed bacterial carbon turnover; it demonstrates also the potential importance of metazoans in energy and material transfer in particles. When large amorphous aggregates appeared in the water column in August and September 1991, the zooplankton species composition obviously changed with the age of marine snow and the living zooplankton biomass was comparatively low in large aggregates. Only in stringers of a few $\mathrm{mm}$ to $\mathrm{cm}$ length did we find polychaete larvae in a density similar to those found in summer 1990 (Table 1).

Shanks \& Edmondson (1990) studied marine snow sedimentation in the Atlantic off North Carolina (USA) and stressed the contribution of meiobenthic species like nematodes to the metazoan community on marine snow. Interestingly, we could not find any nematodes enriched in marine snow, even though the water column at our sampling station did not exceed $15 \mathrm{~m}$ in depth. Besides polychaete larvae, we found large amounts of turbellarians. Adult Convoluta aff. convoluta is usually abundant in the phytal (Apelt 1969). Occasionally, however, they also emerge into pelagic regions where they might become entrapped in marine snow. Hagerman \& Rieger (1981) found large numbers of juvenile acoeles and other soft-bodied meiofauna in sediment trap samples off North Carolina, which indicates the occurrence of meiofauna in the water column due to resuspension. We do not know how many of the harpacticoid copepods we found in marine snow are actually of meiobenthic origin, as we did not distinguish among holoplanktonic, hypoplanktonic and benthic types.

The zooplankton community in marine snow takes advantage of this specific habitat within the pelagic environment. Some organisms we found utilize marine snow as a food source, as direct observations of polychaete larvae, nauplii and Temora stylifera have revealed. Convoluta aff. convoluta relies to a large extent on its endosymbiontic diatoms (Ax \& Apelt 1965) and therefore the juvenile acoeles may benefit from high inorganic nutrient concentration found in marine snow (Kaltenböck \& Herndl 1992). The main fraction of the zooplankton community in marine snow consists of larvae and juveniles (Table 1), which can take advantage of the buoyancy of marine snow for their dispersal. Using inverted sediment traps in addition to conventionally deployed traps, Herndl (in press) showed that marine snow exhibits a bidirectional flux which is obviously influenced by the metabolic activity of marine snow attached microorganisms. The average net flux for marine snow depends on the depth and on the time 
of day. The upward flux can even exceed the downward flux in $4 \mathrm{~m}$ depth during daytime (Herndl in press). The settling velocities of the larval polychaetes not associated with marine snow vary between 22.9 and $108.7 \mathrm{~m} \mathrm{~d}^{-1}$, which lies in the range $(8.64$ to 259.2 $\mathrm{m} \mathrm{d}^{-1}$ ) given by Butman (1986). The water column in the Northern Adriatic Sea does not exceed $35 \mathrm{~m}$ and therefore they would rapidly settle to the bottom. Thus by locating in marine snow, larvae can reduce sedimentation velocity and save energy which is normally expended in active swimming motion and consequently enhance their dispersal.

In oligotrophic marine systems phytoplankton biomass is controlled by zooplankton; consequently, particle flux to the deep ocean is largely mediated in the form of fecal pellets (Knauer et al. 1979, Karl et al. 1988). In eutrophic environments, however, zooplankton cannot cope with the development of phytoplankton; the consequence of this is that phytoplankton becomes senescent as they are inefficiently grazed, leading to massive sinking of decaying cells to the ocean's interior (Smetacek 1985). Particle flux into the aphotic zone or to the bottom occurs therefore not only via fecal pellets but - to a large extent - via ungrazed, decaying phytoplankton cells. In the Northern Adriatic Sea, the formation of large buoyant mucous sheets might be interpreted as a manifestation of a large ungrazed fraction of phytoplankton, especially the part that is embedded in marine snow. The rather insignificant grazing of Acartia clausi on marine snow - as shown in this study - implies that primary production of phytoplankton associated with marine snow does not enter directly the plant-herbivore food web like in the ambient water but is utilized by the heterotrophic microbial consortia. Only a few associated species might act as a metazoan link between primary production and higher trophic levels. The high biomass of heterotrophic organisms which utilize marine snow (bacteria, protozoa and larval stages of metazoa) would lead to a rapid disappearance of aggregates if phytoplankton were not able to take advantage of the liberated nutrients and continually produce mucus (along with other microbes) leading to a remarkable constant marine snow mass throughout the summer.

In summary we have demonstrated that Acartia clausi, which is the dominant copepod in the Northern Adriatic Sea, is not able to feed significantly on the autotrophic compartment in marine snow and that living herbivorous zooplankton is only weakly enriched in small marine snow particles. On the other hand, larval stages of metazoans exhibited high enrichment factors in marine snow and might be, at least occasionally, the dominant consumers (over bacteria) of organic carbon in marine snow, not only in terms of biomass, but also in their carbon demand. We conclude, therefore, that in nearshore marine snow more attention should be paid to these small metazoans as their role in the carbon flux through marine snow might not be trivial.

Acknowledgements. We thank the staff of the Laboratorio de Biologia Marina at Trieste, Aurisina (Italy), and especially S. Fonda-Umani, the Ruder Boskovic Institute at Rovinj (Croatia) and at the Marine Biology Station Prian (Slovenia), for hospitality and laboratory space. Special thanks go to M. Karner and E. Berger for their help throughout the study and the staff of the Cancer Research Institute for making their fluorometer available to us. We are grateful to $\mathrm{M}$. Bhaud for identifying the polychaete larvae and A. Alldredge for comments and fruitful discussions during the preparation of the manuscript. The helpful suggestions and the continuous support by J. A. Ott throughout the study is gratefully acknowledged. This study was supported by the Austrian Science Foundation (FWF grant \# 7748-BIO to G.J.H.), the Osservatorio Alto Adriatico, the Austrian Ministry of Science and Arts (to A.B.B.) and a Theodor-Körner-Fonds grant (to A.B.B.). The work is in partial fulfillment of the requirements towards a M.Sc. degree at the University of Vienna by A.B.B.

\section{LITERATURE CITED}

Alldredge, A. I. (1972). Abandoned larvacean houses: a unique food source in the pelagic environment. Science 177: 885-887

Alldredge, A. L., Cole, J. J., Caron, D. A. (1986). Production of heterotrophic bacteria inhabiting macroscopic organic aggregates (marine snow) from surface waters. Limnol. Oceanogr. 31: 68-78

Alldredge, A. L., Gotschalk, C. C. (1990). The relative contribution of marine snow of different origins to biological processes in coastal waters. Contin. Shelf Res. 10: 41-58

Alldredge, A. L., Silver, M. W. (1988). Characteristics, dynamics and significance of marine snow. Prog. Oceanogr. 20: 41-82

Apelt, G. (1969). Fortpflanzungsbiologie, Entwicklungszyklen und vergleichende Frühentwicklung acoeler Turbellarien. Mar. Biol. 4: 267-325

Ax, P., Apelt, G. (1965). Die 'Zooxanthellen' von Convoluta convoluta entstehen aus Diatomeen. Naturwissenschaften 52: $444-446$

Banse, K. (1990). New views on the degradation and disposition of organic particles as collected by sediment traps in the open sea. Deep Sea Res. 37: 1177-1195

Baylor, E. R. Sutcliffe, J. W. H. (1963). Dissolved organic matter in seawater as a source of particulate food. Limnol. Oceanogr. 8: 369-371

Beers, J. R., Trent, J. D., Reid, F. M. H., Shanks, A. L. (1986). Macroaggregates and their phytoplanktonic components in the Southern California Bight. J. Plankton Res. 8: 475-487

Butman, C. A. (1986). Larval settlement of soft-sediment invertebrates: some predictions based on an analysis of near-bottom velocity profiles. In: Nihoul, J. C. J. (ed.) Marine interfaces ecohydrodynamics. Elsevier, Amsterdam, p. 487-514

Caron, D. A., Davis, P. G., Madin, L. P., Sieburth, J. McN. (1982). Heterotrophic bacteria and bacterivorous protozoa in oceanic macroaggregates. Science 218: 795-797

Cori, C. J. (1906). Über die Meeresverschleimung im Golf von Triest während des Sommers 1905. Arch. Hydrobiol. Planktonkd. 1 385-391 
Dagg, M. J., Wyman, K. D. (1983). Natural ingestion rates of the copepods Neocalanus plumchrus and $N$. cristatus calculated from gut contents. Mar. Ecol. Prog. Ser 13: 37-46

Davoll, P. J., Silver, M. W. (1986), Marine snow aggregates: life history sequence and microbial community of abandoned larvacean houses from Monterey Bay, California. Mar. Ecol. Prog. Ser. 33: 111-120

Fonda Umani, S. (1985). Quantitative contribution of Acartia clausi Giesbrecht and Penilia avirostris Dana to zooplankton biomass in the Gulf of Triest. Atti Congr. naz. Soc. ital. Ecol 5: 235-237

Fonda Umani, S., Coccietto, M. (1988). Tasso di filtratione e d'ingestione di Acartia clausi nel Golf di Trieste. Atti Congr. Ass. ital. Oceanol. Limnol. 8: 383-395

Fowler, S. W., Knauer, G. A. (1986). Role of large particles in the transport of elements and organic compounds through the organic water column. Prog. Oceanogr. 16: 147-194

Gaudy, R. (1974). Feeding four species of pelagic copepods under experimental conditions. Mar. Biol. 25: 125-141

Gifford, D. J., Dagg, M. J. (1988). Feeding of the estuarine copepod Acartia tonsa Dana: carnivory vs. herbivory in natural microplankton assemblages. Bull. mar. Sci. 49: $458-468$

Gnaiger, E. (1983). Calculation of energetic and biochemical equivalents of respiratory oxygen consumption. SpringerVerlag, New York

Hagerman, G. M., Rieger, R. M. (1981). Dispersal of benthic meiofauna by wave current action in Bogue Sound, North Carolina, USA. P.S.Z.N.I. Mar. Ecol. 2(3): 245-270

Herndl, G. J. (1988). Ecology of amorphous aggregations (marine snow) in the Northern Adriatic Sea. II. Microbial density and activity in marine snow and its implication to overall pelagic processes. Mar. Ecol. Prog. Ser. 48: $265-275$

Herndl, G. J. (in press). Marine snow in the northern Adriatic Sea: possible causes and consequences for a shallow ecosystem. Mar. microb. Fd Webs

Herndl, G. J., Peduzzi, P. (1988). Ecology of amorphous aggregations (marine snow) in the Northern Adriatic Sea: I. General considerations. P.S.Z.N.I. Mar. Ecol. 9: 79-90

Jonsson, P. R., Tiselius, P. (1990). Feeding behaviour, prey detection and capture efficiency of the copepod Acartia tonsa feeding on planktonic ciliates. Mar. Ecol. Prog. Ser. 60: $35-44$

Kaltenböck, E., Herndl, G. J. (1992). Ecology of amorphous aggregations (marine snow) in the Northern Adriatic Sea. IV. Dissolved nutrients and the autotrophic component associated with marine snow. Mar. Ecol. Prog. Ser. 87: $147-159$

Karl, D. M., Knauer, G. A., Martin, J. H. (1988). Downward flux of particulate organic matter in the ocean: a particle decomposition paradox. Nature 332: 438-441

Karner, M., Herndl, G. J. (1992). Extracellular enzymatic activity and secondary production in free-living and marine snow associated bacteria. Mar. Biol. 133: 341-347

Klekowski, R. Z. (1971). Cartesian diver microespirometry for aquatic animals. Pol. Arch. Hydrobiol. 18, 93-114

Knauer, G., Martin, J. H., Bruland, K. W. (1979). Fluxes of particulate carbon, nitrogen, and phosphorus in the upper water column of the northeast Pacific. Deep Sea Res. 26: $97-108$

Knauer, G. A., Hebel, D., Cipriano, F. (1982). Marine snow: major site of primary production in coastal waters. Nature 300: 630-631

Lonsdale, D. J., Heinle, D. R., Siegfried, C. (1979). Carnivorous feeding behavior of the adult calanoid copepod Acartia tonsa Dana. J. exp. mar Biol. Ecol. 36: 235-248
Mackas, D., Bohrer, R. (1976). Flucrescence analysis of zooplankton gut contents and an investigation of diel feeding patterns. J. exp. mar Biol. Ecol. 25: 77-85

McCarthy, J. J., Goldman, J. C. (1979). Nitrogenous nutrition of marine phytoplankton in nutrient-depleted waters. Science 203: 670-671

Nival, P., Nival, S. (1976). Particle retention efficiencies of an herbivorous copepod Acartia clausi (adult and copepodite stages): effects on grazing. Limnol. Oceanogr. 21. 24-38

Omori, M., Ikeda, T (1984). Methods in marine zooplankton ecology. John Wiley \& Sons, New York

Parsons, T., Maita, Y., Lalli, C. M. (1984). A manual of chemi$\mathrm{cal}$ and biological methods for seawater analysis. Pergamon Press, Oxford

Raymont, J. E. G. (1983). Zooplankton. Pergamon Press, Oxford

Richman, S., Loya, Y., Slobodkin, L. R. (1975). The rate of mucus production by corals and its assimilation by the coral reef copepod Acartia negligens. Limnol. Oceanogr. 20: $918-923$

Riedl, R. (1985). Fauna und Flora des Mittelmeeres. Paul Parey, Hamburg

Riley, G. A., Wangersky, P. J., Hemert, D. V. (1964). Organic aggregates in tropical and subtropical surface waters of the North Atlantic Ocean. Limnol. Oceanogr. 9: 546-550

Schiemer, F., Novak, R., Ott, J. (1990). Metabolic studies on thiobiotic marine free-living nematodes (Desmodoridae: Stilbonematinae) and their symbiotic microorganisms. Mar. Biol. 106: 129-137

Schnack, S. B. (1983). On the feeding of copepods on Thalassiosira partheneia from the Northwest African upwelling area. Mar. Ecol. Prog. Ser. 11: 49-53

Shanks, A. L., Trent, J. D. (1979). Marine snow: microscale nutrient patches. Limnol. Oceanogr 24: 850-854

Shanks, A. L., Edmondson, E. W. (1989). Laboratory-made artificial marine snow: a biological model of the real thing. Mar Biol, 101: 463-470

Shanks, A. L., Edmondson, E. W. (1990). The vertical flux of metazoans (holoplankton, meiofauna, and larval invertebrates) due to their association with marine snow. Limnol. Oceanogr. 35: 455-163

Sheldon, R. W., Nival, P., Rassoulzadegan, F. (1986). An experimental investivation of a flagellate-ciliate-copepod food chain with some observations relevant to the linear biomass hypothesis. Limnol. Oceanogr. 31: 184-188

Silver, M. W., Gowing, M. M., Brownlee, D. C., Corliss, J. O. (1984). Ciliated protozoa associated with oceanic sinking detritus. Nature 309: 246-248

Silver, M. W., Shanks, A. L., Trent, J. D. (1978). Marine snow: microplankton habitat and source of small-scale patchiness in pelagic populations. Science 201: 371-373

Smetacek, V. (1985). Role of sinking in diatom life-history cycles: ecological, evolutionary and geological significance. Mar. Biol. 84: 239-251

Stachowitsch, M., Fanuko, N., Richter, M. (1990). Mucus aggregates in the Adriatic Sea: an overview of stages and occurrences. P.S.Z.N.I. Mar. Ecol. 11: 327-350

Stoecker, D. K., Capuzzo, M. J. (1990). Predation on Protozoa: its importance to zooplankton. J. Plankton Res. 12: 891-908

Taylor, G. T. (1989). Variability in the vertical flux of microorganisms and biogenic material in the epipelagic zone of a North Pacific central gyre station. Deep Sea Res. 36: $1287-1308$

Taylor, G. T., Pace, M. L. (1987). Validity of eucaryotic inhibitors for assessing production and grazing mortality of marine bacterioplankton. Appl. environ. Microbiol. 53: $119-128$ 
Turner, J. T., Tester, P. A., Ferguson, R. L. (1988). The marine cladoceran Penilia avirostris and the 'microbial loop' of the pelagic food web. Limnol. Oceanogr. 33: 245-255

Wiadnyana, N. N., Rassoulzadegan, F. (1989). Selective feed-

This article was submitted to the editor ing of Acartia clausi and Centropages typicus on microzooplankton. Mar. Ecol. Prog. Ser. 53, 37-45

Zeuthen, E. (1950). Cartesian diver respirometer. Biol. Bull 98: $139-143$

Manuscript first received: March 6, 1992

Revised version accepted: August 11, 1992 